\title{
MANAGEMENT PRACTICES IN AREA OF HUMAN RESOURCES AND MONITORING RESULTS AS DETERMINANTS OF SME'S SUCCESS IN POLAND AND THE CZECH REPUBLIC
}

\section{Krzysztof Łobos' ${ }^{1}$, Vojtěch Malátek², Mirosława Szewczyk ${ }^{3}$}

\footnotetext{
1 WSB University in Wroclaw, Department of Management, ORCID: 0000-0002-7411-4145, krzysztof.lobos@wsb.wroclaw.pl;

2 Silesian University in Opava, School of Business Administration in Karvina, Department of Business and Management, ORCID: 0000-0002-8704-721X, malatek@opf.slu.cz;

3 Opole University of Technology, Faculty of Economics and Management, Department of Economics, Finance and Regional Research, ORCID: 0000-0002-0969-8973, m.szewczyk@po.edu.pl.
}

\begin{abstract}
The main aim of the article is to identify specific management practices of small and medium-sized enterprises (SMEs), which determine processes of their growth and development, and then to determine the character and force of dependence between the identified practices and the growth and development of SMEs. It occurred that the HR practices and the monitoring of results determine significantly the growth and development of small and medium-sized enterprises in Poland and the Czech Republic. In order to accomplish the goal, the authors constructed a model of dependence and also made an evaluation of the significance and force of its influence. The unit data obtained from 383 companies operating on the territory of Poland and 381 ones based in the Czech Republic were used for this purpose. The data were analyzed statistically using structural equation modeling. The results point to, first of all, a substantial direct and indirect impact of HR practices on the growth and development of companies in the examined size class in both countries. We recognized four crucial factors of HR practices: (1) attracting talented people to the company, (2) rewarding well, (3) causing that employees know precisely their tasks, decision areas and responsibilities, (4) running an SME enterprise in such a way as to promote cooperation between employees and to create a good working climate. In addition to traditional human resource management practices, we observe in SMEs the need for introduction more humanistic management models focused on building commitment and employee satisfaction. The influence of HR practices on the growth and development of an enterprise is additionally strengthened by the monitoring of results. In the case of Polish enterprises, there is a direct impact of the monitoring of results on the development of a company. In the case of Czech enterprises, we have to do only with an indirect influence of monitoring practices on the company's development. Among studied monitoring of results variables, three should be particularly stressed. It is essential that managers and leaders define targets and measures of meeting the targets. The results obtained by the company should be also presented and discussed and monitored on a continuous basis. Results could allow SME's practitioners a better understanding of crucial factors they ought to focus their management efforts.
\end{abstract}

Keywords: SME, growth, development, human resources.

JEL Classification: L21, M50, C49.

APA Style Citation: Łobos, K., Malátek, V., \& Szewczyk, M. (2020). Management Practices in Area of Human Resources and Monitoring Results as Determinants of SME's Success in Poland and the Czech Republic. E\&M Economics and Management, 23(2), 114-125.

https://doi.org/10.15240/tul/001/2020-2-008 


\section{Introduction}

Towards the end of the 1980s, all the countries of the former socialist bloc had to wrestle with structural and systemic problems. At the moment of entering the period of transformations, Poland and Czechoslovakia were characterized by different conditions, among others, GDP per capita, the range of macroeconomic imbalance, inflation rate, indebtedness, or the share of the private sector. In Poland, private ownership dominated in agriculture, while in trade and service its share was significant. On the other hand, as regards Czechoslovakia, private ownership was scarce. The 1990s saw far-reaching systemic changes going on both in Poland and Czechoslovakia (and following the split of the latter - the Czech Republic). Privatization of enterprises was the fundamental part of the economic reforms program implemented in both countries.

The introduction of free market principles, the influx of foreign investment and restructuring actions, undoubtedly influenced the change in the way enterprises functioned in the market. At present, small and mediumsized enterprises are of the key importance to the economic development of Poland and the Czech Republic. The transformations which have occurred in the economies of the states - former members of the socialist bloc - during the last quarter century have made it legitimate for researchers to apply, for instance, Polish or Czech terms which have been already used by market economies of longstanding traditions, to describe the functioning of enterprises with reference to such companies.

The aim of the work is to identify specific management practices of small and mediumsized enterprises (SMEs), which determine processes of their growth and development, and then to determine the character and force of dependence between the identified practices and the growth and development of SMEs. The research was conducted in March 2017 with the use of the Internet-assisted survey questionnaire (CAWI) in Poland and the Czech Republic. The analysis was carried out on the unit data obtained from 383 enterprises operating on the territory of Poland and 381 companies based in the Czech Republic. Structural equation modeling was used in the analyses.

Many researchers have studied determinants of firm growth and development.
This study both supports and adds to the existing literature. The added value of our research relates to the proposal of a unique theoretical model, which examines the relationship between practices in area of human resources, monitoring results and the growth and development of SME companies in Poland and the Czech Republic. Outcomes inform about the key aspects of HR practices and monitoring that should be improved for playing a more decisive role in the growth and development efforts of SMEs.

\section{Theoretical Framework and Hypothesis Development}

Resource-based view suggests a dependence of the growth of small firms on having at their disposal specific resources not only in the material or financial senses but also in that of skills. Dynamic skills, being one of the growth factors, consist in acquiring, integrating, reconfiguring and using resources suitably to the market situation (Eisenhardt \& Martin, 2000). A carrier of these skills is the human factor, though. Thus, in fact, it needs inclining towards the statement that this growth factor and the quality of human resources must be taken into account (Cressy, 2006; Koeller \& Lechler, 2006; Adamska \& Minárová, 2014).

Human resources have certainly been one of the key areas in the transition process in post-communist Europe. The labor market was not functioning, with high levels of overemployment. Unemployment inevitably increased sharply at the start of the transition. A sharp contraction in state firms was offset by the private sector expansion. Small and medium-sized enterprises have played a significant role in setting the transition economies onto the path of convergence with UE countries. For most countries, labour market reform, economic growth, and emigration have helped reduce unemployment over time.

The significance of HR practices regarding incomes, value, growth, and development of companies is confirmed by numerous empirical studies. Here, an example is the research of the Human Capital Index $(\mathrm{HCl})$ conducted by Watson Wyatt Company. That study concentrated on looking for relations between the quality of HR practices and the company's value. The analysis of HR practices allowed identifying HR practices which have a positive influence on the market value of the company. 
There is an extensive literature on the subject of human resources management (Bainbridge, Sanders, Cogin, \& Lin, 2017; Markoulli, Lee, Byington, \& Felps, 2017). Some authors focused their research on transition economies (Zupan \& Kaše, 2005; Milikić, Janićijević, \& Petković, 2008; Bainbridge, Sanders, Cogin, \& Lin, 2017; Egerová, Lančarič, Eger, \& Savov, 2015; Sokolova, Zubr, Cierniak-Emerych, \& Dziuba, 2019). Tung and Havlovic (1996) stated that many Czech human resources practices are similar to the ones created in the industrialized West. The process of privatization influenced the organizational structure of firms in transitional economies (Cooke, Wood, Psychogios, \& Szamosi, 2011; Horwitz, 2011). There seems to be a widespread agreement that human resources are the main source of the success of small or medium-sized enterprise (Dany, Guedri, \& Hatt, 2008; Jakubów, 2005; Strużyna, 2007; Strużyna, Majowska, \& Ingram, 2009). Łobos and Szewczyk (2012) found that smaller firms exhibit the lowest survival probability. Among them firms employing regular workers overperform in terms of survival rate, thus the decision on employment is rational and substantially justified. The survey by Egerová, Lančarič, Eger and Savov (2015) indicated that talent management was not a matter of primary concern to most organisations in the Czech Republic and Slovakia. Brzostek and Michna (2016), Allen, Ericksen and Collins (2013) studied the impact of human resource management practices on the performance of firms. Švárová and Vrchota (2013) evaluated the links between strategic management and firm performance in micro, small and medium-sized businesses. Results indicate that construction companies with a clearly defined strategy show better results of corporate financial performance than companies without a defined strategy.

Hence, we may formulate the following hypotheses:

H1a: HR practices have a positive influence on the growth of a firm.

H1b: HR practices have a positive influence on the development of a firm.

The literature gives conflicting evidence about whether Investors in People (IIP) practices improve organizational performance. Bourne, Franco-Santos, Pavlov, Lucianetti, Martinez and Mura (2008) found a link between the adoption of the Investors in People Standard and business performance. IIP practices in an organization have a positive effect on business performance, both the non-financial performance and the financial performance of the business (Bourne, Franco-Santos, Pavlov, Lucianetti, Martinez, \& Mura, 2008). In contrast, Ram (2000) reported IIP as "irrelevant and inappropriate" for SMEs context. Investors in People (IIP) do not grow to a higher degree than firms which do not invest in people (Foreman-Peck, Makepeace, \& Morgan, 2006). Fraser (2003) noted that the impact of IIP on a small firm is neutral; businesses that choose IIP achieve enhanced growth as a result of their investments.

Adaptation to environmental changes is an important theme in organization theory literature (Sharfman \& Dean, 1997; Dreyer \& Grønhaug, 2004; Grewal \& Tansuhaj, 2001). A company has an opportunity of achieving success in its surrounding only when it continuously monitors the latter and confronts the results with the internal potential at the disposal. Monitoring enables adaptation and improves over time. Empirical studies have shown that strategic flexibility can have a significant positive effect on firm performance (Yang, 2010; Alpkan, Yılmaz, \& Kaya, 2007; Nadkarni \& Narayanan, 2007; Grewal \& Tansuhaj, 2001). Wherever entry barriers protect a firm, flexibility issues arise when the need for endogenous changes occurs (Harrigan, 2017). The important step in the strategic human resource management process is to compare the performance of the human resource strategy against the preestablished targets.

This article attempts to contribute to the debate concerning role of monitoring of results but not specifically in strategic planning process but rather in general process of SME functioning. Strategic management is not because the most typical type of management for SME companies.

Hence, we consider the following hypotheses:

H2a: Monitoring results has a positive influence on the growth of a firm.

$\mathrm{H} 2 \mathrm{~b}$ : Monitoring results has a positive influence on the development of a firm.

In Poland and the Czech Republic, comprehensive structural reforms helped to develop a vibrant small and medium-sized enterprise sector. "Polish small and medium enterprises are in the initial stage of life cycle and are characterized by growth rather than development with mainly quantitative success factors" (Jakubów, 2005). 
Hence, we consider the following hypothesis:

H3: Development has a positive influence on the growth of a firm.

In this study, growth and development represent two aspects of the success of the surveyed SME-class enterprises. In addition to them, the authors also distinguish other areas of success, such as enterprise survival and material and social stability, which, however, did not participate in this study. They create a kind of logical sequence: (1) material and social balance understood as the lack of threat to the continuity of functioning, enables focusing on pro-growth activities (2) growth processes create economic potential enabling improvement and justifying this improvement, (3) development processes support feedback enterprise survival (4). The relationship is circular in its nature. Company's growth should be defined as improvement in all measurable, and at the same time, key aspects of the company's functioning, such as: market and distribution, production, basic economic and financial categories, staff or cooperation with other entities. Thus, examples of growth will be: an increase in market share and an increase in the number of markets or clients served, an increase in the number of distribution channels, an increase in production volume, an increase in the company's turnover, an increase in employment, an increase in the number of business partners and others not listed here. In other words - the growth of an enterprise means expanding the scale and scope of its activities as well as increasing employment or turnover. The development of the enterprise reflects the improvement of the key areas of enterprise functioning. These areas can only be described with the help of hardly measurable, qualitative variables. Development means improvement in such areas as: competitive position, economic condition, enterprise management system, customer service system and customer relations, market offer, method of cooperation and cooperation with subcontractors, general efficiency of operations.

\section{Materials and Methodology}

The aim of the work was to identify specific management practices of small and mediumsized enterprises (SMEs), which have significant influence on such dimensions of their success as growth and development. Then, the specific aim was to create a model of dependence, which would explain, in a complex way, the causal links between these practices and the growth and development of SMEs.

The survey covered companies employing from 10 to 249 people (firms employing up to 9 people were excluded from the research). The analysis was based on the unit data obtained from enterprises based on the territories of Poland (383 enterprises) and the Czech Republic (381 enterprises). The authors chose the proportionate stratified sampling method (the number of elements in each stratum is proportionate to their numbers in the given population). The general population was divided into strata, taking into account the size of the given company: the first stratum - companies employing 10-49 people, the other stratum enterprises employing 50-249 people, and then a direct sampling of relevant entities within each stratum was done. The survey was conducted in March 2017 with the use of CAWI (Computer-Assisted Web Interviewing).

The essence of modeling structural equations consists in reflecting interdependences between directly unobservable hidden variables through the application, for this purpose, of observable measurement indicators. Each of the hidden variables (HR practices, monitoring results) is measured with an ordered set of empirical variables (indicators). The variables serving as indicators in the estimation model were measured on a 7-degree scale (strongly disagree -1 , disagree -2 , somewhat disagree -3 , neither agree nor disagree -4 , somewhat agree -5 , agree -6 , strongly agree -7 ) .

The growth of companies was operationalized by the following fourphenomena: the rise in the number of customers, the rise in the number of employees, the rise in the companies' revenues, the rise in the company's value. The development of enterprises was operationalized by three phenomena: perfecting the management system, perfecting the market offer, the development of cooperation with other subjects in the market. The question was asked if in the last three years the respondents had had to deal with the above-mentioned phenomena (Tab. 1).

Depending on a review of previous studies, we developed a research model (Fig. 1).

Cronbach's alpha coefficient was used to assess the factors of internal reliability. In order to assess the adjustment of the model the following were used: the goodness-of-fit index 


\section{Fig. 1: Proposed theoretical model}

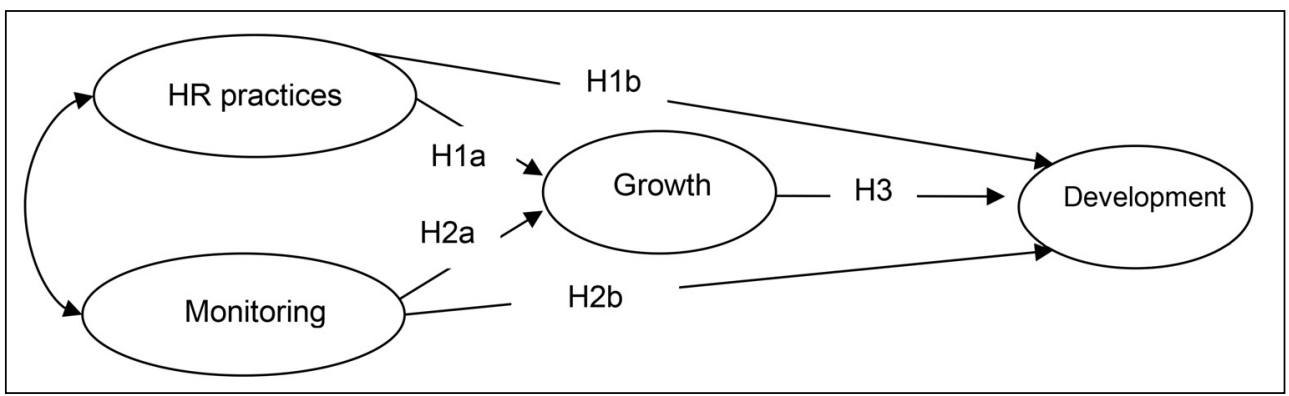

Source: own

\section{Tab. 1: Specification of model indicators}

\begin{tabular}{|c|c|c|}
\hline $\begin{array}{c}\text { Latent } \\
\text { variable }\end{array}$ & Item description & $\begin{array}{l}\text { Variable } \\
\text { label }\end{array}$ \\
\hline \multirow{5}{*}{ HR practices } & $\begin{array}{l}\text { We act purposefully and actively for attracting talented people to the firm and } \\
\text { later we try to retain them in the company. }\end{array}$ & $\mathrm{X}_{1}$ \\
\hline & Our workers are well-paid. & $\mathrm{X}_{2}$ \\
\hline & $\begin{array}{l}\text { Each person in our firm knows exactly the description of their tasks, areas of } \\
\text { decision and responsibility. }\end{array}$ & $\mathrm{X}_{3}$ \\
\hline & $\begin{array}{l}\text { It is very important for us to manage the company in such a way that people } \\
\text { cooperate and work in a good organizational climate. }\end{array}$ & $\mathrm{X}_{4}$ \\
\hline & We let go people who are ineffective at work. & $\mathrm{X}_{5}$ \\
\hline \multirow{5}{*}{$\begin{array}{l}\text { Monitoring } \\
\text { results }\end{array}$} & I have a detailed list of targets of my firm to meet. & $\mathrm{X}_{6}$ \\
\hline & $\begin{array}{l}\text { I have concrete measurements which show me how far am I advanced in } \\
\text { reaching the targets. }\end{array}$ & $\mathrm{X}_{7}$ \\
\hline & $\begin{array}{l}\text { Each employee in my firm knows exactly their own targets, measures of } \\
\text { meeting the targets and the scope of their responsibilities. }\end{array}$ & $\mathrm{X}_{8}$ \\
\hline & $\begin{array}{l}\text { In our firm, the results obtained by each employee responsible for the given } \\
\text { area are presented and discussed. }\end{array}$ & $\mathrm{X}_{9}$ \\
\hline & $\begin{array}{l}\text { In our firm, the results obtained by the company are monitored } \\
\text { on a continuous basis. }\end{array}$ & $\mathrm{X}_{10}$ \\
\hline \multirow{4}{*}{ Growth } & In the last three years, there has followed an increase in the number of customers. & $Y_{1}$ \\
\hline & In the last three years, there has followed an increase in the number of workers & $Y_{2}$ \\
\hline & In the last three years, the company has increased its revenues. & $\mathrm{Y}_{3}$ \\
\hline & $\begin{array}{l}\text { In the last three years, there has followed an increase in the value of the } \\
\text { company. }\end{array}$ & $\mathrm{Y}_{4}$ \\
\hline \multirow{3}{*}{ Development } & In the last three years, the company has improved its system of management. & $Y_{5}$ \\
\hline & In the last three years, the company has perfected its market offer. & $Y_{6}$ \\
\hline & $\begin{array}{l}\text { In the last three years, the development of partner cooperation with other } \\
\text { firms in the market has been observed. }\end{array}$ & $Y_{7}$ \\
\hline
\end{tabular}


GFI, the adjusted goodness of fit index AGFI and the Gamma index.

The contributions of the study should be viewed in light of several limitations. In terms of coverage, this study is limited to Poland and the Czech Republic and the results might not suitable to other countries. The study is a cross-sectional in nature, thus data were collected at one point in time. The use of a selfrating development measure may constitute a limitation of the study. Finally, from a technical perspective, the survey results are based on selected variables due tu size requirements for structural equation models (5-10 observations per estimated parameter).

\section{Results and Discussion}

Part of the determinants of companies' growth and development, recognized as a result of a systematic review of the literature, was used in the conducted research (data of this kind were collected in the enterprises) but were not included in the final model. The leading example of this is the entrepreneurial orientation described in the theoretical part, which was not included in the ultimately accepted model.
The analysis of measurement reliability displayed a high level of internal agreement in the case of monitoring results, HR practices, growth and development (Tab. 2).

The formal basis to accept the model was the assessment of results in the goodnessof-fit tests (GFI, AGFI, Gamma). The results obtained in the tests of goodness of fit to the output model (Fig. 1) proved the adjustment to be poor. Therefore, the decision was taken to test alternative models through the elimination of the output model of chosen paths (statistically insignificant or of low values of standardized coefficients of the paths).

The conducted analyses revealed a series of relevant dependencies (Tab. 3, Tab. 4, Fig. 2, Fig. 3). They also allowed identifying the model of development of Polish and Czech enterprises.

The obtained pattern of results points primarily to a significant direct and indirect impact of HR practices on the growth and development of enterprises (both Polish and Czech ones). Hence, hypotheses $\mathrm{H} 1 \mathrm{a}$ and $\mathrm{H} 1 \mathrm{~b}$ are confirmed. The influence of HR practices on the growth and development of an enterprise

\section{Tab. 2: Cronbach's Alpha values}

\begin{tabular}{l|c|c}
\multicolumn{1}{c|}{ Variable } & Poland & Czech Republic \\
\hline Monitoring of results & 0.85 & 0.86 \\
\hline HR practices & 0.70 & 0.74 \\
\hline Growth & 0.84 & 0.82 \\
\hline Development & 0.72 & 0.75 \\
\hline
\end{tabular}

Source: own, STATISTICA

Tab. 3: Structural models for Poland and the Czech Republic

\begin{tabular}{c|l|c|c}
\multirow{2}{*}{ Hypothesis } & \multicolumn{1}{|c|}{ Path } & \multicolumn{2}{c}{ Result } \\
\cline { 2 - 4 } & \multicolumn{1}{|c}{ Poland } & Czech Republic \\
\hline $\mathrm{H} 1 \mathrm{a}$ & HR practices $\rightarrow$ Growth & Supported & Supported \\
\hline $\mathrm{H} 1 \mathrm{~b}$ & HR practices $\rightarrow$ Development & Supported & Supported \\
\hline $\mathrm{H} 2 \mathrm{a}$ & Monitoring $\rightarrow$ Growth & Not supported & Not supported \\
\hline $\mathrm{H} 2 \mathrm{~b}$ & Monitoring $\rightarrow$ Development & Supported & Not supported \\
\hline $\mathrm{H} 3$ & Growth $\rightarrow$ Development & Supported & Supported \\
\hline
\end{tabular}


is additionally strengthened by the monitoring of results. The results of the realized research are confirmed in the literature on the subject. The significance of human resources from the point of view of the company growth is fairly commonly confirmed in studies (Cressy, 2006; Koeller \& Lechler, 2006; Coleman, 2007). A strong and direct dependence of the company's growth and its development on HR practices, which occurs in the case of both Polish and Czech enterprises, is - in the authors' opinion - a peculiar sign of times. Concern for the quality of human resources will to a greater and greater extent determine the success of the enterprise described in the categories of its development, as well as its growth in the times of wage-earning emigration, aging of European societies and the so-called employee's market. The unemployment to date has remained under stronger and stronger influence of shortage of workforce. On the other hand, we come to deal with a significant phenomenon of wage-earning immigration, e.g. from Ukraine. However, it has not compensated the outflow up to date, especially that of the highly-qualified workforce from the markets of the examined countries.

In post-communist countries, we note a kind of disbelief in the power of modern management methods. This state of affairs changes, for instance with inflow of foreign investments and management methods, however, the remains of traditional management models are too visible in many enterprises, both large and small. In the latter case, intuitive management is quite common. It is certainly in Poland. Entrepreneurs prefer a technical and financial approach to management, and innovations in the area of human resource management are treated as not serious. This situation will probably change over time. This study indicates, that areas such as concern for creating a good working climate and promoting cooperation attitudes between employees are a task for companies, that want to attract and maintain the highest quality human capital. Not only high salary and good working conditions, but also employee satisfaction and working climate are valued right now in Czech and Poland as well. We will probably be in the near future witnesses of the growing role of humanistic, so-called soft management methods in countries where Taylorism has dominated so far.

In the case of Polish enterprises, there is a direct impact observable of monitoring of results on the development of a company $(\mathrm{H} 2 \mathrm{~b})$. This impact is additionally strengthened by HR practices. In the case of Czech enterprises, there is only an indirect influence noticeable which monitoring of results has on a company's development. A possible cause of this is a different culture of work, which requires supervising and continuous controlling to a lesser extent. Such factor as commitment can probably complement the deficiency in monitoring activities.

Strong dependences can indicate that the growth of small enterprises is a significant determinant of their development in the sense of the quality of the management system, market offer or cooperation with entities which function

\section{Fig. 2: Weights of the paths in the structural model (Poland)}

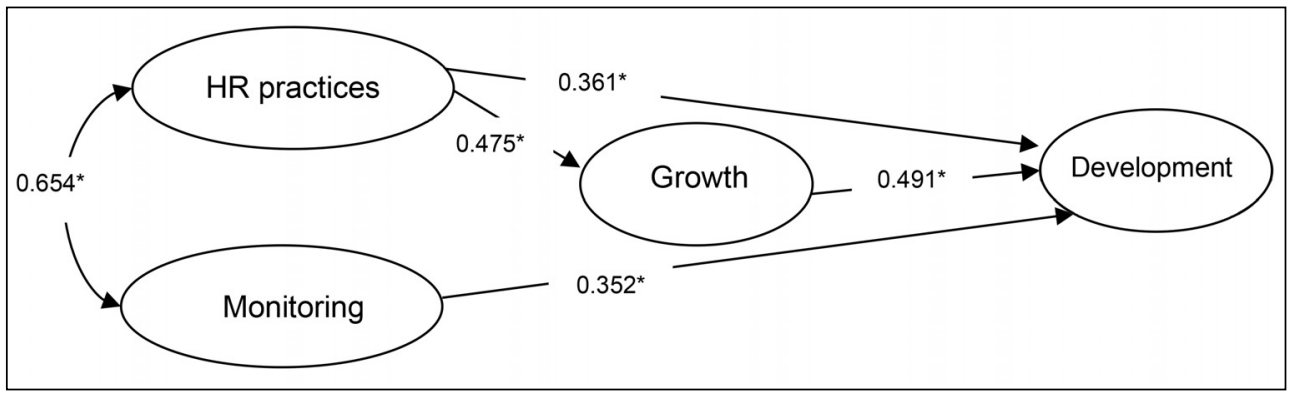

Source: own, STATISTICA

Note: $\mathrm{GFI}=0.884, \mathrm{AGFI}=0.844, \mathrm{Gamma}=0,912$;

* - Statistically significant at $p<0.05$. 


\section{Fig. 3: Weights of the paths in the structural model (Czech Republic)}

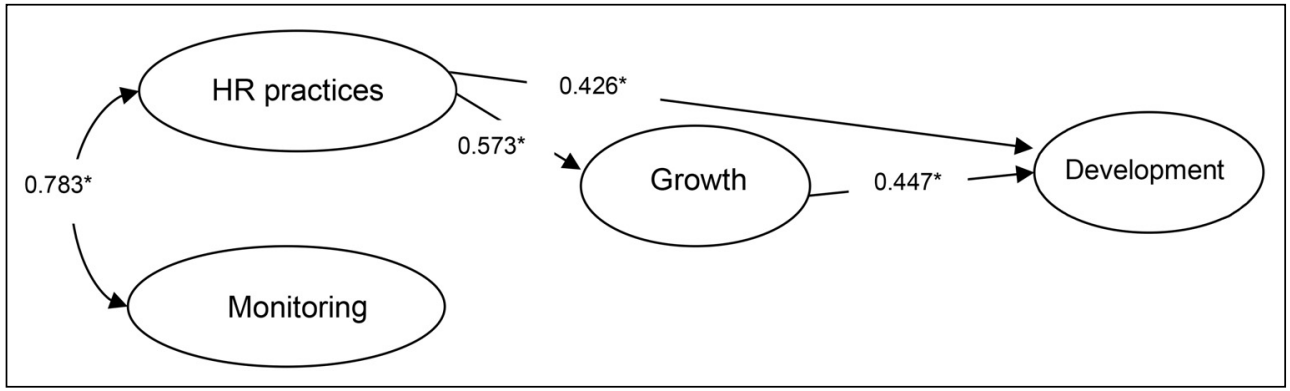

Source: own, STATISTICA

Note: $\mathrm{GFI}=0.854, \mathrm{AGFI}=0.805, \mathrm{Gamma}=0.860$;

* - Statistically significant at $p<0.05$.

in the surrounding environment. The results of this research support the hypothesis that growth has an influence on the development of a firm (H3). This is in agreement with the conclusions made by Jakubów (2005). This can be regarded as an additional result of

\section{Tab. 4: Estimates of the parameters in the model}

\begin{tabular}{|c|c|c|c|}
\hline \multirow{2}{*}{ Path } & \multicolumn{2}{|c|}{ Estimate of path weight } & \multirow{2}{*}{ P-value } \\
\hline & Poland & Czech Republic & \\
\hline HR practices $\rightarrow X_{1}$ & 0.972 & 1.000 & $p<0.001$ \\
\hline HR practices $\rightarrow X_{2}$ & 0.826 & 1.031 & $p<0.001$ \\
\hline HR practices $\rightarrow X_{3}$ & 0.779 & 0.974 & $p<0.001$ \\
\hline HR practices $\rightarrow \mathrm{X}_{4}$ & 0.686 & 0.756 & $p<0.001$ \\
\hline HR practices $\rightarrow X_{5}$ & 0.332 & 0.663 & $p<0.001$ \\
\hline Monitoring $\rightarrow \mathrm{X}_{6}$ & 1.315 & 1.340 & $p<0.001$ \\
\hline Monitoring $\rightarrow X_{7}$ & 1.372 & 1.266 & $p<0.001$ \\
\hline Monitoring $\rightarrow \mathrm{X}_{8}$ & 0.986 & 1.147 & $p<0.001$ \\
\hline Monitoring $\rightarrow \mathrm{X}_{9}$ & 1.051 & 1.083 & $p<0.001$ \\
\hline Monitoring $\rightarrow \mathrm{X}_{10}$ & 0.971 & 1.195 & $p<0.001$ \\
\hline Growth $\rightarrow Y_{1}$ & \multicolumn{3}{|c|}{ N.a. } \\
\hline Growth $\rightarrow Y_{2}$ & 1.021 & 0.775 & $p<0.001$ \\
\hline Growth $\rightarrow Y_{3}$ & 1.241 & 1.131 & $p<0.001$ \\
\hline Development $\rightarrow \mathrm{Y}_{4}$ & 1.208 & 0.802 & $p<0.001$ \\
\hline Development $\rightarrow \mathrm{Y}_{5}$ & \multicolumn{3}{|c|}{ N.a. } \\
\hline Development $\rightarrow \mathrm{Y}_{6}$ & 0.734 & 1.122 & $p<0.001$ \\
\hline Development $\rightarrow \mathrm{Y}_{7}$ & 0.711 & 0.854 & $p<0.001$ \\
\hline
\end{tabular}


the present study. It can be assumed that the growth of SME enterprises precedes their development and is a kind of development catalyst. It seems, based on the collected data, that the increase in revenues, the number of employees, the number of customers or cooperators triggers processes of improving the way the company operates - its development. In the author's opinion, such a relationship has a logical reason. Small and mediumsized enterprises usually develop not so much synoptically as incrementally. Their decisionmakers usually do not anticipate achieving a certain level of development in advance, but carry out development activities when there is a rational economic premise, they need it, and this premise is the growth of the enterprise and the increase in the number of operations that need to be carried out more efficiently, better, faster or cheaper. Such a path of dependence may be particularly typical for earlier stages of enterprise development, because in the next, mature stages, one can also speak of the feedback effect of development on growth processes.

Our results identify four crucial factors related to HR practices (Tab. 4):

- attraction talented people to the company, and then acting in the direction to retain them;

- the importance of salary;

- knowledge of tasks, decision areas, and responsibilities;

- running an SME enterprise in such a way as to promote cooperation between employees and to create a good working climate (which is a novelty in SME enterprises managed largely intuitively by the owners-managers unfamiliar with modern management models).

Hence, SMEs should pay particular attention in their choice of employees, since these choices can have a critical impact on the growth and development of the firm and then to recognize the determinants which influence the retainment of the employee process. SMEs should improve the process of attraction of talented people (what is mainly realised by care of relations with employees and building a good image as an employer in Internet). On the other side is the termination of employment people with low performance. However, the weight of this factor is smaller than a robust talent strategy.
The results provide some signals that all tested forms of monitoring have strong importance (Tab. 4). Among the variables studied, two should be mentioned. It is essential that managers and leaders define targets and measures of meeting the targets. In connection to the need of the use of more humanistic management models, we want to propose to lead verification of results in the cooperative process in which participate actively two sides management and subordinates, as for instance proposed in Management by Objectives. There is also a clear need for presenting and discussing obtained results, what seems to be the next signal of expectation for some more cooperative management. The results obtained by the company should be monitored on a continuous basis.

In consequence of the conducted empirical research it was possible to determine certain universal dependencies; however, differences in the results indicate that specifics of the examined country can be decisive in determining relevant factors of growth and development of enterprises.

\section{Conclusions}

Management practices is an important topic in the management literature. However, we still have much to learn. Our findings extend the understanding of the role of HR practices and monitoring practices for the SME growth and development. Results of the modeling show that HR practices are of key pro-developmental significance for small and medium-sized enterprises. We can observe also in SME companies a need for more humanistic attitude in management process (collaboration of employees, climate of work, participative discussion of results). Data show the evidence of the importance of implementing a clear policy of talents attraction and retainment. The intensifying difficulty in finding specialists, which has grown even stronger in recent years, is a consequence of structural maladjustment, that is the qualifications held by people who are willing to take employment rarely suit the needs of employers. The problem is getting more and more severe, posing a serious barrier to the development of not only individual firms but the whole of the countries' economies. Poland and the Czech Republic are in the lead regarding the states with the highest level of wageearning emigration in Central-Eastern Europe. 
This leads to the practical conclusion that HR practices, which are focused on building workers' commitment and satisfaction with their work, will be a key determinant of growth and development of small companies in the successive years to come.

The impact of HR on the growth and development of an enterprise is additionally strengthened by the monitoring of results. It seems that monitoring of results reflects also the significance of an organization's flexibility - its ability to adapt to changing conditions in the surrounding environment. Practices of monitoring of results are of particular significance to the growth and development of small companies. They arise from the need to reach assumed business targets and the necessity of functioning of the system of controlling targets met by the employees, the best in participative way which stimulates commitment.

\section{References}

About the Watson Wyatt Human Capital Index. (2003). Retrieved May 10, 2018, from http://www.workforce.com/2003/09/18/aboutthe-human-capital-index-study/

Adamska, M., \& Minárová, M. (2014). Role of learning organization in building consumer confidence. E\&M Economics and Management, 17(1), 62-72. https://doi.org/10.15240/tul/001/ 2014-1-005

Allen, M. R., Ericksen, J., \& Collins, C. J. (2013). Human resource management, employee exchange relationships, and performance in small businesses. Human Resource Management, 52(2), 153-173. https://doi.org/10.1002/hrm.21523

Alpkan, L., Yilmaz, C., \& Kaya, N. (2007). Market Orientation and Planning Flexibility in SMEs. International Small Business Journal, 25(2), 152-172. https://doi. org/10.1177/0266242607074518

Bainbridge, H. T., Sanders, K., Cogin, J. A., \& Lin, C. H. (2017). The pervasiveness and trajectory of methodological choices: A 20year review of human resource management research. Human Resource Management, 56(6), 887-913. https://doi.org/10.1002/ hrm. 21807

Bourne, M., Franco-Santos, M., Pavlov, A., Lucianetti, L., Martinez, V., \& Mura, M. (2008). The Impact of the Investors in People Standard on people management practices and firm performance (Study report). Cranfield: Cranfield School of Management, Centre for Business Performance. Retrieved from http://dspace.lib.cranfield.ac.uk/handle/1826/4305

Brzostek, K., \& Michna, A. (2016). Empirical Studies Concerning the Relationship between Knowledge Management and Effective Performance in Small- and Medium-Sized Enterprises: Selected Preliminary Results. In Advancing Research in Entrepreneurship in the Global Context Conference Proceedings of the 8th ENTRE Conference (pp. 67-78). https://doi. org/10.7172/1644-9584.62.3

Coleman, S. (2007). The Role of Human and Financial Capital in the Profitability and Growth of Women-Owned Small Firms. Journal of Small Business Management, 45(3), 303-319. https://doi.org/10.1111/j.1540627x.2007.00214.x

Cooke, L. F., Wood, G., Psychogios, G. A., \& Szamosi, T. L. (2011). HRM in emergent market economies: evidence and implications from Europe. Human Resource Management Journal, 21(4), 368-378. https://doi.org/10.1111/ j.1748-8583.2011.00181.x

Cressy, R. (2006). Why do most firms die young? Small Business Economics, 26(2), 103-116. https://doi.org/10.1007/s11187-004-7813-9

Dany, F., Guedri, Z., \& Hatt, F. (2008). New insights into the link between HRM integration and organizational performance: the moderating role of influence distribution between HRM specialists and line managers. The International Journal of Human Resource Management, 19(11), 2095-2112. https://doi. org/10.1080/09585190802404320

Dreyer, B., \& Grønhaug, K. (2004), Uncertainty, flexibility, and sustained competitive advantage, Journal of Business Research, 57(5), 484-494. https://doi.org/10.1016/s01482963(02)00315-6

Duspivová, M., \& Krninská, R. (2013). Human resources management within the process management in small and medium-sized enterprises. Acta Universitatis Agriculturae et Silviculturae Mendelianae Brunensis, 61(7), 2093-2098. https://doi. org/10.11118/actaun201361072093

Egerová, D., Lančarič, D., Eger, L., \& Savov, R. (2015). Perspectives of talent management: evidence from Czech and Slovak business organisations. E\&M Economics and Management, 18(4), 108-121. http://dx.doi. org/10.15240/tul/001/2015-4-008 
Eisenhardt, K. M., \& Martin, J. A. (2000). Dynamic capabilities: What are they? Strategic Management Journal, 21(10-11), 1105-1122. https://doi.org/10.1002/10970266(200010/11)21:10/11\%3C1105::aidsmj133\%3E3.0.co;2-e

Foreman-Peck, J., Makepeace, G., \& Morgan, B. (2006). Growth and profitability of small and medium-sized enterprises: Some Welsh evidence. Regional Studies, 40(4), 307-319. https://doi.org/10.1080/00343400600725160

Grewal, R., \& Tansuhaj, P. (2001). Building Organizational Capabilities for Managing Economic Crisis: The Role of Market Orientation and Strategic Flexibility. Journal of Marketing, 65, 67-80. https://doi.org/10.1509/ jmkg.65.2.67.18259

Hamel, G. (2000). Leading the revolution. Cambridge, MA: Harvard University Press.

Harrigan, K. R. (2017). Strategic flexibility and competitive advantage. In Oxford Research Encyclopedia of Business and Management. https://doi.org/10.1093/ acrefore/9780190224851.013.2

Horwitz, F. M. (2011). Future HRM challenges for multinational firms in Eastern and Central Europe. Human Resource Management Journal, 21(4), 432-443. https://doi.org/10.1111/j.1748-8583.2011.00185.x

Jakubów, L. (2005). Źródła sukcesów małych i średnich przedsiębiorstw w Polsce. Prace i Materiały Wydziału Zarządzania Uniwersytetu Gdańskiego, 5, 298-301.

Koeller, C. T., \& Lechler, T. G. (2006). Economic and managerial perspectives on new venture growth: An integrated analysis. Small Business Economics, 26(5), 427-437. https://doi.org/10.1007/s11187-005-5068-8

Leaptrott, J., \& McDonald, J. M. (2008). Looking Before Leaping: The Effect of Owner Decisiveness on Small Business Performance. Academy of Entrepreneurship Journal, 14(1-2), 1-12. Retrieved May 10, 2018, from https://www.abacademies.org/articles/ aejvol14nos1and22008.pdf\#page $=11$

Markoulli, M. P., Lee, C. I., Byington, E., \& Felps, W. A. (2017). Mapping Human Resource Management: Reviewing the field and charting future directions. Human Resource Management Review, 27(3), 367-396. https://doi.org/10.1016/j.hrmr.2016.10.001

Milikić, B. B., Janićijević, N., \& Petković, M. (2008). HRM in Transition Economies: The Case of Serbia. South East European Journal of Economics and Business, 3(2), 75-88. https://doi.org/10.2478/v10033-008-0017-5

Nadkarni, S., \& Narayanan, V. K. (2007). Strategic Schemas, Strategic flexibility, and firm performance: The moderating role of industry clockspeed. Strategic Management Journal, 28(3), 243-270. https://doi.org/10.1002/smj.576

Ram, M. (2000). Investors in People in Small Firms: Case study evidence from the business services sector. Personnel Review, 29(1), 69-91. https://doi.org/10.1108/00483480010295826

Sharfman, M. P., \& Dean, J. W. Jr. (1997). Flexibility in strategic decision making: Informational and ideological perspectives, Journal of Management Studies, 34(2), 191-217. https://doi.org/10.1111/1467-6486.00048

Sokolova, M., Zubr, V., Cierniak-Emerych, A., \& Dziuba, S. T. (2019). The Level of Organizational Culture as a Constant Challenge for Company Management - an Empirical Research in the Czech Republic and Poland. E\&M Economics and Management, 22(1), 145-157. https://dx.doi.org/10.15240/ tul/001/2019-1-010

Strużyna, J. (2007). Sukces organizacji na tle koncepcji kapitału ludzkiego i zasobów ludzkich. Prace i Materiały Wydziału Zarządzania Uniwersytetu Gdańskiego, (1), 95-101.

Strużyna, J., Majowska, M., \& Ingram, T. (2009). Ostrożne szacowanie wartości organizacji w oparciu o jakość zarządzania zasobami ludzkimi. Zeszyty Naukowe Uniwersytetu Szczecińskiego. Finanse. Rynki finansowe. Ubezpieczenia, (17), 220-229.

Švárová, M., \& Vrchota, J. (2013). Strategic management in micro, small and medium-sized businesses in relation to financial success of the enterprise. Acta Universitatis Agriculturae et Silviculturae Mendelianae Brunensis, 61(7), 2859-2866. https://doi.org/10.11118/ actaun201361072859

Szewczyk, M., \& Łobos, K. (2012). Survival analysis: A case study of micro and small enterprises in Dolnośląskie and Opolskie Voivodship (Poland). Central European Review of Economic Issues, Ekonomická Revue, 15, 207-216. https://doi.org/10.7327/ cerei.2012.12.01

Tung, R. L., \& Havlovic, S. J. (1996). Human resource management in transitional economies: The case of Poland and the Czech Republic. International Journal of Human Resource Management, 7(1), 1-19. https://doi. org/10.1080/09585199600000115 
Vlachos, I. P. (2009). The effects of http://en.cnki.com.cn/Article_en/CJFDTOTALhuman resource practices on firm growth. International Journal of Business Science and Applied Management, 4(2), 17-34. https://doi. org/10.1201/b12878-7

Yang, Z., Deng, L. J., \& Fang, E. (2010). Market orientation, strategic flexibility, and performance: The moderating effect of environmental uncertainty. China Soft Science, 46(9), 130-139. Retrieved May 10, 2018, from

ZGRK201009015.htm

Zupan, N., \& Kaše, R. (2005). Strategic human resource management in European transition economies: building a conceptual model on the case of Slovenia. The International Journal of Human Resource Management, 16(6), 882-906. https://doi. org/10.1080/09585190500120525 